\title{
Single Permit Issues of Online Submission (OSS)
}

\author{
Desi Ayuwati ${ }^{*}$, Gunarto $^{* *}$ and Soegianto ${ }^{* * *}$ \\ *) Students of Master of Notary Law, Universitas Islam Sultan Agung (UNISSULA) \\ Semarang, E-Mail: desiayuwati25@gmail.com \\ ${ }^{* *}$ Lecturer of Master of Notary Law, Universitas Islam Sultan Agung (UNISSULA) \\ Semarang \\ ${ }^{* * *}$ Lecturer of Master of Notary Law, Universitas Islam Sultan Agung (UNISSULA) \\ Semarang
}

\begin{abstract}
The purpose of this study was to: 1) To analyze the implementation problems of Online Single Submission (OSS) in Indonesia. 2) To analyze the constraints and find solutions permitting the implementation of Online Single Submission (OSS) in the PTSP. The data used in this study are primary data, secondary data and data that can support tertiary study, which was then analyzed by descriptive analytical method. Based on the results of data analysis concluded that: 1) Problems OSS among others: first, Presidential Regulation No. 24 of 2018 does not set the transition effect. Secondly, the OSS system is not ready, partly because of computer systems across ministries and agencies, both at central and local levels that have not been connected properly. CMEA Nasution admitted that the government has not fully prepared to implement OSS. Third, related NSPK of K/L and LGs. 2)Presidential Regulation No. 24 of 2018 has been set PTSP but only the definition in Article 1 point 28 and General Explanation of PTSP. In General Explanation mentioned that Presidential Regulation No. 24 of 2018 perfecting the OSS on the central government and local governments to become more efficient, serve, and modern. In the body of Presidential Regulation No. 24 of 2018 no provisions to the PTSP. The absence of regulation PTSP in Presidential Regulation No. 24 of 2018 lead to confusion in practice, given the PTSP is a designated institution Article 25 paragraph (4) and (5) Investment Law.
\end{abstract}

Keywords: Single Permit; Online Submission (OSS).

\section{Introduction}

Licensing trying to become one of the service areas that still need to be addressed related to order execution. Licensing sought is necessary approvals entrepreneurs to start and run businesses and be given in the form of approval set forth in the form of a letter/decision or eligibility (checklist). Problems on licensing is also available on the investor complaints. In early 2018 the Investment Coordinating Board (BKPM) reported that there were five (5) investor complaints about barriers to investment that is made up of the inconsistency of regulations, taxes, quality of labor, availability of land and barrier construction permits, as well as the quality of infrastructure ${ }^{1}$.

\footnotetext{
${ }^{1}$ Tangkilisan, Hessel Nogi. (2003). Kebijakan Publik Yang Membumi. Yogyakarta: Lukman Offset YPAPL. p.65-66
} 
The Indonesian government seeks to improve the efficiency of operations by accelerating the implementation of trying arranged in Government Regulation No. 24 Of 2018 concerning Integrated Licensing Services Sought In Electronic. Based on the policy, all business licensing services be integrated by the center through one (1) Trying Electronic Licensing System Online Single Submission (OSS) ${ }^{2}$.

Through OSS service ${ }^{3}$ system, all maintenance business license can be done in a way that is easy, fast, accurate and efficient. For companies the requirement as in general that must first take care of the legality of the enterprise through the notary and for individual businesses simply by using Population Identification Number. Currently the problems that occurred in the application execution Trying Licensing Services Online Single Integrated Electronic Submission ${ }^{4}$ (OSS) that people who are not accustomed to using online means or afraid of input data. Based on these problems, now all can be resolved with a simple way is to come to the One Stop Services (OSS) nearby. The arrangement in accordance with the principle of legality which states the government authority comes from legislation. The principle of legality is the basis of legitimacy of government action and guarantee protection of the rights of the people. In other words, every organization of state and government must have the principle of legitimacy. Application of the principle of legality, according to Indroharto, will support the enactment of legal certainty and equality of treatment. According Indroharto, without the basic authority granted by a legislation in force, all kinds of government officials it would not have the authority to influence or change the state or the legal position of their peoples ${ }^{5}$.

Issuing of licenses sought by the Institute does not undermine the authority BKPM OSS. Pursuant to Article 27 paragraph (1) and (2) Investment Law, coordinate government policy of investments made by the BKPM. One of the duties and functions of BKPM ie coordinate and implement the one stop service ${ }^{6}$. That is, the Investment Act authorizes the coordination and carrying out PTSP BKPM and not the authority to give permission sought. The authority gives permission sought remains with the minister, the leadership of the institution, governor or regent/mayor.

Presidential Regulation No. 24 of 2018 has been set PTSP but only the definition in Article 1 point 28 and General Explanation of PTSP. In General Explanation mentioned that Presidential Regulation No. 24 of 2018 perfecting the OSS on the central government and local governments to become more efficient, serve, and modern. In the body of Presidential Regulation No. 24 of 2018 no provisions to the PTSP. The absence of regulation PTSP in Presidential Regulation No. 24 of 2018 lead to confusion in practice, given the PTSP is a designated institution Article 25 paragraph (4) and (5)

\footnotetext{
${ }^{2}$ Winarno, Budi. (2005). Implementasi Kebijakan Publik Teori dan Proses. Jakarta: PT Buku Kita.p.121

${ }^{3}$ Deen, Thaufiq., Victoria, O. Argo., \& Sumain. (2018). Public Notary Services In Malaysia. JURNAL AKTA: Vol. 5, No. 4, 1017-1026. Retrieved from http://jurnal.unissula.ac.id/index.php/akta/article/view/4135

${ }^{4}$ Rizal, dkk. (2018). Implementasi Pelayanan Terpadu Satu Pintu di Kabupaten Enrekang. STISIP Muhammadiyah Rappang.p.43

${ }^{5}$ lbid.

${ }^{6}$ Article 28 letter j Act No. 25 of 2007
} 
Investment Law. In practice, the OSS service operations within six months after its release will be transferred to the BKPM starting in January 2019. Head of BKPM Thomas Lembong say, ready to strengthen the OSS services in order to increase the amount of investment in Indonesia ${ }^{7}$.

\section{Research Methods}

The author uses descriptive study specification analysis ${ }^{8}$, that is explained, describe or disclose the legislation in force associated with the theories of positive law and in practice the implementation of the law concerning the above problems. Descriptive aims to measure accurately against certain social phenomena and gives an overview of symptoms which are at issue were discussed, while the study is an analysis aimed at analyzing the problems arising in the study ${ }^{9}$.

\section{Results and Discussion}

Some of the problems in the implementation of OSS licensing seeks, first, Presidential Regulation No. 24 of 2018 does not set the transition effect. Presidential Regulation No. 24 of 2018 effective immediately upon promulgation, ie June 21, 2018, while still permitting set out in Annex PP that can not be served through OSS systems ${ }^{10}$. Facility Services Director BKPM Endang Supriyadi states, the agency learned on June 28, 2018 that the PP takes effect immediately without a transition period. BKPM itself when it has issued thousands of licenses without going through the OSS, as well as $\mathrm{K} / \mathrm{L}$ central, provincial, and district/city. BKPM has requested legal opinion of the Attorney General related to thousands of licenses already issued them. On August 26, 2018, the Attorney General issued an opinion that all licenses issued since June 21, Particularly related to the process of issuing permits sought by the OSS system ${ }^{11}$.

Second, The OSS system not ready yet, partly because the computer system among ministries and institutions, in the central or areas not connected properly. CMEA Nasution admitted that the government has not fully prepared to implement OSS. One of the problems is of 514 regencies and cities in Indonesia, only 45 counties and cities that have digital RDTR, so the licensing process can be done online location ${ }^{12}$. According to the Expert Staff of National Competitiveness Development Coordinating Ministry of Economic Affairs, Lestari Indah, OSS system is still being developed in the direction of the portal. There are three basic principles OSS.

First, OSS is a national portal to take care of all the licensing business in Indonesia. Before any OSS, every ministry and every region, has its own application system. The second

\footnotetext{
${ }^{7}$ lbid.

${ }^{8}$ Moleong, Lexy. (2000). Metode Penelitian Kualitatif. Bandung: Remaja Rosdakarya. p. 87

${ }^{9}$ Sugiyono. (2010). Metode Penelitian Pendidikan Pendekatan Kuantitatif, Kualitatif dan R\&D. Bandung: Alfabetha. p. 54

${ }^{10}$ BKPM, October $18^{\text {th }}, 2018$

${ }^{11}$ Hukumonline.com, November 26, 2018

12 Op.Cit.
} 
principle, one identity. This means that every company in Indonesia, either individually must have known the identity of NIB. Third, the consent form. First business license depending on who publish both letters, letterhead and signature. With the existence of the portal will allow investors who want to invest in any location in Indonesia, already a standard, so it is not confusing ${ }^{13}$. Third, related NSPK of K/L and LGs.Pursuant to Article 88 paragraph (5) Presidential Regulation No. 24 of 2018 trying to set licensing standards no later than 15 days following the issuance of Presidential Regulation No. 24 of 2018. However, according to Endang Supriyadi, until now there has been all NSPK of K/L and the Government in accordance with the PP that have an impact on the legality of OSS licenses that have been published without NSPK of sectors. The next major issue, one of the standard system integration Presidential Regulation No. 24 of 2018 includes digital signatures inter licensing trying to OSS systems. Whereas, pursuant to Article 52 of Act No. 30 of 2014 on Government Administration stated that the requirement of the validity of the decision, among others, include the establishment by the competent authority. To note, the OSS licensing currently only has a QR code with no digital signature ${ }^{14}$.

Therefore, the government need to follow up problems in the permit sought electronically revise Presidential Regulation No. 24 of 2018 as synchronization with the Investment Law in terms of setting and determination PTSP competent authorities in the form of digital signature. To cope with the OSS system is not ready, the government should accelerate the availability of the connectivity of computer systems among $\mathrm{K} / \mathrm{L}$ in the center and regions. The government also needs to encourage the adjustment NSPK of $\mathrm{K} / \mathrm{L}$ and the local government by the Presidential Regulation No. 24 of 2018.

In Presidential Regulation No. 24 of 2018 has been set PTSP but only the definition in Article 1 point 28 and General Explanation of PTSP. In General Explanation mentioned that Presidential Regulation No. 24 of 2018 perfecting the OSS on the central government and local governments to become more efficient, serve, and modern. In the body of Presidential Regulation No. 24 of 2018 no provisions to the PTSP. The absence of regulation PTSP in Presidential Regulation No. 24 of 2018 lead to confusion in practice, given the PTSP is a designated institution Article 25 paragraph (4) and (5) Investment Law.

\section{Closing}

Based on the results of data analysis concluded that: 1) Problems OSS among others: first, Presidential Regulation No. 24 of 2018 does not set the transition effect. Secondly, the OSS system is not ready, partly because of computer systems across ministries and agencies, both at central and local levels that have not been connected properly. CMEA Nasution admitted that the government has not fully prepared to implement OSS. Third, related NSPK of K/L and LGs. 2)Presidential Regulation No. 24 of 2018 has been set PTSP but only the definition in Article 1 point 28 and General

\footnotetext{
${ }^{13}$ Wartakota.com, November 26, 2018

${ }^{14}$ Loc.Cit.
} 
Explanation of PTSP. In General Explanation mentioned that Presidential Regulation No. 24 of 2018 perfecting the OSS on the central government and local governments to become more efficient, serve, and modern. In the body of Presidential Regulation No. 24 of 2018 no provisions to the PTSP. The absence of regulation PTSP in Presidential Regulation No. 24 of 2018 lead to confusion in practice, given the PTSP is a designated institution Article 25 paragraph (4) and (5) Investment Law.

\section{References}

Journal:

Deen, Thaufiq., Victoria, O. Argo., \& Sumain. (2018). Public Notary Services In Malaysia. JURNAL AKTA: Vol. 5, No. 4, 1017-1026. Retrieved from http://jurnal.unissula.ac.id/index.php/akta/article/view/4135

Books:

[1] Islamy, Irfan. (2003). Prinsip-prinsip Perumusan Kebijaksanaan Negara. Jakarta: Bina Aksara Moleong.

[2] Moleong, Lexy. (2000). Metode Penelitian Kualitatif. Bandung: Remaja Rosdakarya

[3] Rizal, dkk. (2018). Implementasi Pelayanan Terpadu Satu Pintu di Kabupaten Enrekang. STISIP Muhammadiyah Rappang.

[4] Sugiyono. (2010). Metode Penelitian Pendidikan Pendekatan Kuantitatif, Kualitatif dan R\&D. Bandung: Alfabetha.

[5] Tangkilisan, Hessel Nogi. (2003). Kebijakan Publik Yang Membumi. Yogyakarta: Lukman Offset YPAPL.

[6] Winarno, Budi. (2005). Implementasi Kebijakan Publik Teori dan Proses. Jakarta: PT Buku Kita.

Regulations:

[1] Act No. 25 of 2009 on the Public Service.

[2] Act No. 23 of 2014 on Regional Government.

[3] Regulation of the Minister of Home Affairs Number 24 Of 2004 on Guidelines for Providing One Stop.

[4] Presidential Decree Number 91 Of 2017 About Accelerating Implementation Effort.

[5] Government Regulation No. 24 of 2018 on the Implementation of Licensing Services Integrated Electronic Trying.

News: 
[1] BKPM, October 18th, 2018

[2] Hukumonline.com, November 26, 2018

[3] Wartakota.com, November 26, 2018 